\title{
Debt Collection Violations in Financial Technology in a Cyber-ethic and Legal Perspective
}

\author{
http://dx.doi.org/10.25008/jkiski.v6i1.510 \\ Wawan Edi Prastiyo $^{1 *}$, I Dewa Made Suartha ${ }^{2}$ \\ ${ }^{1,2}$ Faculty of Law, Universitas Udayana \\ J1. Pulau Bali No.1, Denpasar 80114 - Indonesia \\ *Corresponding author: wawanep@mahkamahagung.go.id
}

Submitted: February 03, 2021, Revised:March 17, 2021, Accepted: April 14, 2021

Accredited by Kemristekdikti No. 28/E/KPT/2019

\begin{abstract}
The presence of financial technology (Fintech) on the one hand makes it easy for people to obtain credit, while on the other hand, it creates various problems. In this study, two issues will be discussed, namely the application of cyber-ethic in protecting personal data and legal issues in collecting debt on Fintech. This research is a qualitative research. Data in the study were collected by means of literature study and presented descriptively and analytically. Cyber-ethic is implemented by protecting personal data. It is a transformation of traditional ethics in cyberspace. The cyber-ethic is very necessary in the business world. The application of cyber-ethic in the world of Fintech is carried out by protecting the personal data of both borrowers and third parties. Cyber-ethic violations have implications for breaking the law. Some of the billing violations on the Fintech business are sexual harassment, defamation, threats and stalking. Borrowing customers are powerless to face debt collectors' behavior, because the debt collectors use the borrowers' personal data to exert psychological pressure on the debtors to pay according to the bills determined unilaterally by Fintech. This condition usually occurs in illegal Fintechs that are not registered with the Financial Services Authority.
\end{abstract}

Keywords: Violation; debt collection; fintech; cyber ethic; legal perspective

\section{Introduction}

Financial technology (Fintech) is the result of a combination of financial services and technology which ultimately changes the business model from conventional to moderate. In the beginning, transactions had to be face-to-face and carried some cash, now remote transactions can be made by making payments in just seconds. According to the Financial Stability Board, Fintech is a form of technology-based financial innovation that can produce new business models, applications, processes or products with material effects related to financial markets, institutions and service providers (Suharini, S., \& Hastasari, R., 2020). Fintech is centered on the innovative use of smart mobile devices to design and deliver financial services and products, enhancing innovative ways of providing financial services (Al-Mudimigh, A., \& Anshari, M., 2020).

Historically, fintech is a financial product and service through a combination of technology platforms and innovative business models, while the origins of fintech itself came from Silicon Valley, one of the southern parts of the San Fansisco Bay Area in California. This internetbased financial service has since expanded to New York, Singapore, Hong Kong, and several global countries. In an Asian country like Singapore, it is a place where technology and trust form the basis for an innovative line of financial services. Peer to peer lending has roots in Singapore and is valued for directly linking borrowers and loan recipients. Singapore has a cash-intensive economy in which there are a lot of lending and the lending is already 
done outside Singapore, this is one of the reasons that makes Singapore conducive to the development of alternative credit systems, especially the development of online lending platforms that aim to provide access to capital to SMEs. Meanwhile in Indonesia, there are startups that have generated around US \$ 56 million. Fintech funding is a peer-to-peer lending market in which third-party lenders provide cash and which benefit in return (Novinna, V., 2021).

The presence of fintech in Indonesia is regulated in the Financial Services Authority Regulation Number 77/Pojk.01/2016 concerning Information Technology-Based Borrowing and Lending Services. Article 1 point 3 of the Financial Services Authority Regulation Number 77/Pojk.01/2016 concerning Information Technology-Based Borrowing and Lending Services stipulates that "Information TechnologyBased Lending and Borrowing Services are the provision of financial services to bring lenders to meet loan recipients in the framework of entering into a loan agreement, borrow directly in rupiah currency through an electronic system using the internet network."

Provisions on Fintech are also contained in Bank Indonesia Regulation Number 19/12/PBI/2017 concerning the Implementation of Financial Technology. Article 1 Number 1 of Bank Indonesia Regulation Number 19/12/ PBI/2017 concerning the Implementation of Financial Technology states that Financial Technology is the use of technology in the financial system which results in new products, services, technology and/or business models and can have an impact on monetary stability, financial system, and/or efficiency, smoothness, security and reliability of the payment system. Bank Indonesia's policy response to the development of financial technology must remain synchronous, harmonious and integrated with other Bank Indonesia policies, such as the implementation of payment transaction processing and national payment gateways and must be coordinated with relevant authorities.

As of January 10, 2021, the total number of fintech peer-to-peer lending or fintech lending operators registered and licensed at the OJK is 149 companies (https://www.ojk.go.id/id/kanal/iknb/financialtechnology/Pages/Fintech-Lending-OperatorsRegistered-and-Licensed-at-OJK-per-10-January2021.aspx). The main advantages of Information Technology-Based Lending and Borrowing Services include the availability of agreement documents in electronic form online for the purposes of the parties, the availability of legal counsel to facilitate online transactions, online risk assessment of parties, online submission of billing information (collection), provision of information on loan status to parties online, and provision of escrow and virtual accounts in banking to parties, so that all payments of funds take place in the banking system. For this reason, Information Technology-Based Lending and Borrowing Services are expected to be able to meet cash needs quickly, easily and efficiently, as well as increase competitiveness (Terminanto, A. A., 2020).

Deputy Director of Fintech Regulation, Research and Development, Financial Services Authority, Munawar Kasan, said that lending through peer to peer lending (P2P) in 2020 reached IDR 74.41 trillion. This figure is up 26.47 percent when compared to the same period in the previous year. The distribution of these loans is also higher than that of other financial services industries. On the loan disbursement side in 2020, IDR 74.41 trillion means that YoY has increased by 26.47 percent, in terms of growth in distribution, it is quite high, although it is not as high as the previous year. OJK noted that there are around 45 million user accounts, this is an increase compared to the previous year when the figure was recorded at 43.5 million user or borrower accounts (https://www.liputan6.com/bisnis/read/4485532/p enyaluran-pinjaman-fintech-p2p-lending -in-2020reached-rp-7441-trillion). However, there are several communication ethics problems that lead to legal problems.

Through the Jendela service, the Indonesian Joint Funding Fintech Association has opened a public information service and complaints regarding the funding by fintech industry since March 2019 on the AFPI website. The association noted that throughout $2020,46 \%$ of the complaints were related to unethical billing. This is followed by the category of complaints about restructuring at $22.52 \%$, the category of complaint containing questions and input from the public at $17.74 \%$, the category of complaint about personal data breach at $7.7 \%$ and the category of complaint about interest rate at $5.23 \%$ (https://keuangan.kontan.co.id/news/afpipenagihan-tidak-beretika-paling-diadukankonsumen-fintech-p2p). In case of late payments, the organizer hires collectors to collect debts. At the time of billing the collector not only contacts the person concerned but also other telephone numbers on the loan recipient's smartphone contact list that are not found in the emergency contact. This condition puts the loan recipient in a disadvantage position due to this incident. Billing also uses violence and threats that make the borrower uncomfortable. Even though installments have been paid, collectors continue to 
contact and threaten to spread the photos and personal data of the loan recipient in order to pay off the debt immediately (Shofiyah, E. N., \& Susilowati, I. F., 2019).

One of the various alleged violations results from public complaints received by the Jakarta Legal Aid Institute (LBH) since 2018. LBH Jakarta recorded 14 violations of law and human rights experienced by victims of online loan applications. These violations include very high interest without limitation, billing made not only to the borrower but also emergency contacts included by the borrower, threats, slander, fraud and sexual harassment, dissemination of personal data, distribution of photos and loan information to contacts on the borrower's cellphone, taking almost all access to the borrower's cellphone, unclear contact and location of the office of the online loan application organizer, unclear admin fees, the application's act to change name without notifying the borrower, while loan interest continues to grow (Wahyuni, RAE, \& Turisno, BE, 2019). In Indonesia, there are many criminal cases experienced by illegal online loan customers, such as taking personal data to be abused, billing with threats and even sexual harassment through electronic media. Such a case happened to a customer, identified by his initials as YI, in the city of Solo in July 2019 when the debt collector misused his personal data and spread his photo by saying he was willing to be "used sexually" for Rp. $1,054,000$ to pay for an online loan. The case later went viral on social media (Nurwahridya, 2021).

Communication ethics in debt collection through information technology-based lending and borrowing services is needed. The implementation of these practices is highly influenced by Industry 4.0 technology's enablers, particularly within the context of ethical and sustainable business development (Shayganmehr, M., Kumar, A., Garza-Reyes, J. A., \& Moktadir, M. A., 2021). In this study, two issues will be discussed, namely the application of cyber-ethic in protecting personal data and legal issues in collecting debt on fintech. The purpose of this research is related to communication and law.

\section{Theoretical Framework}

Ethical theory in the cyber world or what is called cyber ethics or netiquette was put forward by Thurlow. According to Thurlow, netiquette comes from the word net which means network (network/internet) and etiquette which means ethics or values. Simply put, netiquette is an ethic in using the internet (Nasrullah, 2017). According to Richard A. Spinello, ethics is defined as the application of ethics that describes moral, legal and social issues in the development and use of cyber technology. He also defines cyber technology as a large spectrum stretching from computer devices to a group of information and communication networks (Fardlyan, 2017). Internet ethics or cyber ethics (cyber-ethics) is an adoption of traditional ethical concepts that are applied to the context of the use and development of computer technology and internet networks (Fardlyan, 2017).

Internet and social media users mean that all information transactions that occur on social media cannot be accessed from an ethical aspect. Therefore, netiquette or cyber-ethic is very important to be studied further. Ethics in cyberspace (netiquette) is different from other forms of ethics and needs special study because the communication process that occurs uses technology to communicate, even though the communication process in cyber media is a form of communication in the real world. This is a new phenomenon which is not always implemented properly. Netiquette is the rules and procedures for using the internet as a means of communication or data exchange between groups of people in an internet-mediated system (Fahrimal, Y, 2018).

Netiquette is clearly the cornerstone of the main attitude that is important to apply to social media use. Publishing is not just a publication, commenting is not just a comment without being based on ethics, it is also a superego (Ramadhon, F.N., 2019). Nasrullah at least mentioned five reasons. First, equal media users and come from the same environment. Second, communication that occurs in the media tends to rely on individual texts. Third, in cyber media content is not only directed (directly) to the desired user, but can occur indirectly. Fourth, cyber media does not immediately respond as a media that is different and independent from the real world. Fifth, internet ethics is needed so that every user understands his rights and obligations as 'citizens' of the virtual world (Nasrullah, R., 2014).

\section{Material and Methodology}

This research is a qualitative research. The data source comes from literature study. Researchers used primary legal materials consisting of statutory regulations and secondary legal materials, namely scientific books and journals, as well as electronic articles. Recording was done electronically using a laptop. Approach to the problem is carried out by a regulatory, a legal concept, and a philosophical approach. The study was conducted with cyber-ethic theory, in which the obligation to protect personal data is a protection of human rights. Analysis of the 
problem was carried out by descriptive analytical method.

\section{Result and Discussion}

The rapid development of information technology has implications on changes in the financial business system. Fintech appears in line with changes in people's lifestyles which are currently dominated by users of information technology, the demands of a fast-paced life. Fintech has an impact on society at large by providing access to financial products so that transactions become more practical and effective, such as transacting via smartphones, paying with eMoney, even investing, problems in buying and selling transactions and payments such as not having time to find goods at shopping places, to banks/ATMs to transfer funds, reluctance to visit places because unpleasant services can be minimized and now everything can be done easily. Therefore, transactions which were previously made in person or face to face can now be done even remotely in a matter of seconds. In other words, fintech makes purchase and sale transactions and payment systems more efficient and economical but still effective (Sinaga, H. D. E., Irawati, N., \& Kurniawan, E., 2019). Fintech actually uses technological sophistication for a preexisting financial transaction process, moving to the digital realm, so that the problem will certainly be more complex, because the form of security guarantees will be chiefly prioritized (Fachrurrazy, M., \& Siliwadi, DN, 2020).

The presence of fintech can also put pressure on informal financial service businesses, such as moneylenders. Fintech will change the mindset and business strategy from a traditional conservative business to a collaborative one between real business and fintech players. The collaboration carried out by Tekfin also allows companies to be able to grow faster at lower costs. Collaboration between companies and fintech is generally carried out through venture capital investments, business incubation programs, innovation laboratory programs, strategic partnerships, and accelerator programs for the fintech business. Banks can also collaborate with fintech institutions by creating new business lines in the field of payments, utilizing the expertise of fintech institutions in risk assessment, experience in customer service, operational efficiency, and efficient financing (Yuliana, R. R. R. D., 2019).

The presence of technology in lending and borrowing services is carried out by indirect communication, namely communication that is entirely carried out in cyberspace. Even though communication is carried out in cyberspace, communication ethics is still built into this business pattern. Cyber-ethics seeks to examine the effects of the use of cyber technology on social, legal, and moral systems (Adetimirin, A., 2017). Business actors as part of society cannot separate themselves from the norms and values that apply in their society. Besides, they have to follow the norms and values that apply in the business community. The distrust and powerlessness received by some business people will also affect the distrust of the Indonesian nation as a whole. In terms of business ethics, this is important because it is a manifestation of moral values. Some business people realize that if they want to be successful in business activities, they must heed ethical principles.

Enforcing business ethics is increasingly important in an effort to uphold a conducive climate of healthy competition. Nowadays, many business competitors are engaged in practices that are far from ethical values. Therefore, they conflict with moral standards. Business actors have dared to dominate certain commodity markets by no longer heeding business courtesies. This situation is increasingly crucial as a result of the Government's attitude which provides opportunities for several companies to control the industrial sector from upstream to downstream (Wahyuni, R. A. E., \& Turisno, B. E., 2019). In the fintech business, communication ethics and protection of personal data are priorities.

The increasing global competition encourages the participants of the financial system to use fintech. On the one hand, modern financial technology accelerates the functioning of the financial system, increases its profitability, and opens access to capital markets for new participants. On the other hand, the use of various financial innovations within the framework of fintech results in the creation of potentially unstable environment characterized by a high degree of uncertainty. The transformation of the financial system includes the changes in its institutional design, characteristics, and the number of elements, as well as in the behavior of its participants that takes place (Shkodina, I., Timoshenkov, I., \& Nashchekina, O., 2018). The right to privacy through data protection is not only important but also a key element for individual freedom and dignity (Priskarini, I. A., \& Tejomurti, K., 2019).

The right to privacy is one of the rights that must always be respected and protected because it is one of the rights contained in the Universal Declaration of Human Rights (UDHR). The right to privacy in international legal instruments is seen as a human right. Article 12 The Universal 
Declaration of Human Right states "No one shall be subjected to arbitrary interference with his privacy, family, home or correspondence, nor to attacks upon his honor and reputation. Everyone has the right to the protection of the law against such interference or attacks. "In Article 28G paragraph (1) of the 1945 Constitution of the Republic of Indonesia states that "Every person has the right to protection of himself, family, honor, dignity and property under his control, as well as to a sense of security and protection from threats, fear of doing or not doing something that is a basic right."

According to UNICEF, the development of technology and the internet to become the right to privacy has become a little more complex where in addition to providing convenience on the one hand, the internet also raises new and various threats such as identity theft, cybercriminals, and hackers who take advantage of the e-commerce business (Nurdiani, IP, 2020).

Article 2 of Bank Indonesia Regulation Number 19/12/PBI/2017 concerning the Implementation of Financial Technology, Bank Indonesia governs the implementation of Financial Technology to encourage innovation in the financial sector by applying the principles of consumer protection as well as risk management and prudence in order to maintain monetary and financial stability and payment system that is efficient, smooth, safe, and reliable. Article 1 number 27 of Government Regulation of the Republic of Indonesia Number 82 of 2012 concerning the Management of Electronic Transactions and System stipulates that Personal Data is certain individual data which is stored and kept for the truth and its confidentiality is protected. Article 15 of the Government Regulation of the Republic of Indonesia Number 82 of 2012 concerning the Management of Electronic Transactions and System stipulates that Personal Data places a legal obligation on fintech operators to protect personal data as follows:

Electronic System Operators must: (1) maintain the confidentiality, integrity and availability of the personal data they manage; (2) guarantee that the acquisition, use and utilization of personal data is based on the consent of the owner of the personal data, except otherwise stipulated by laws and regulations; and (3) guarantee that the use or disclosure of data is carried out based on the consent of the owner of the personal data and in accordance with the purpose for which it was conveyed to the owner of the personal data at the time of data collection.

In case of a failure to protect the confidentiality of the personal data they manage, the Electronic System Operators are obliged to notify the owner of the personal data in writing. Further provisions regarding the guidelines for the protection of personal data in Electronic Systems as referred to in paragraph (2) are provided for in a Ministerial Regulation.

Article 26 of Law Number 19 of 2016 concerning Amendments to Law Number 11 of 2008 concerning Electronic Information stipulates (1) Except otherwise stipulated by laws and regulations, the use of any information via electronic media relating to the personal data of an individual must be carried out with the consent the related person. (2) Any person whose rights as referred to in paragraph (1) are violated can file a lawsuit for the losses incurred under this Law. In the Elucidation of Article 26, it is stated that in the use of Information Technology, the protection of personal data is a part of personal rights (privacy rights). Personal rights contain the following meanings: (1) Personal rights are the right to enjoy private life and free from all kinds of disturbances; (2) Personal right is the right to be able to communicate with other people without spying; (3) Personal right is the right to supervise access to information about a person's personal life and data.

\section{Legal Issues in Fintech Debt Collection}

A well-known business today that involves the internet media is Online Credit Loans or what is referred to as fintech. This online loan business is generally taken advantage of by the people of Indonesia and is seen as a solution to get loans without collateral for consumptive purposes. It is true that many people argue that this business really helps them to obtain credit, but they do not understand this business directly, especially its legal consequences (BF, A. R. H., Wisudawan, I. G. A., \& Setiawan, Y, 2020). Warren and Brandheis with the development and advancement of technology, there is a public awareness that any person has the right to enjoy life. The right to enjoy life is defined as a person's right which cannot be disturbed in his personal life either by other people or by the state; therefore, the law must recognize and protect the right to privacy (Dewi, 2009). In practice, several legal problems occur in debt collection.

Violation of personal data is quite common in the fintech business. In principle, consumer personal data must be managed according to the principle of fair information practices. This principle is a standard principle used in practice by the public or private sector; therefore, consumer privacy is protected. The Fair Information Principles are as follows: (1) The principle of collection (collection limitation): the collection of 
private public information must be limited to its original purpose; (2) Information dissemination (disclosure): the individual must be provided with information for the purpose of gathering and disseminating information; (3) Secondary use (secondary usage): an individual can refuse other party to collect his personal information without prior consent; (4) Data correction (record correction): there must be a mechanism that allows someone to correct his information; (5) Security: Government agencies that manage and collect personal information are required to ensure the security of information they manage to avoid misuse of the information by others (Shinta Dewi, 2009).

Article 26 of the Financial Services Authority Regulation Number 77/Pojk.01/2016 concerning Information Technology-Based Lending and Borrowing Services stipulates that Providers are required to: (1) maintain the confidentiality, integrity and availability of personal data, transaction data and financial data that they manage from the time when the data is obtained until it is destroyed;(2) ensure the availability of authentication, verification and validation processes that support non-discretion in accessing, processing and executing personal data, transaction data and financial data that they manage; (3) guarantee that the acquisition, use, utilization and disclosure of personal data, transaction data and financial data obtained by the operator is based on the consent of the owner of the personal data, transaction data and financial data, except otherwise stipulated by provisions in laws and regulations; (4) provide other communication media besides the Information Technology-Based Lending and Borrowing Services Electronic System to ensure the continuity of customer service, which may come in the form of electronic mail, call centers, or other communication media; and (5) notify the owner of the personal data, transaction data and financial data in writing in case of a failure to protect the confidentiality of personal data, transaction data and financial data that they manage.

It is very important to protect personal data relating to population and demographics in Indonesia such as ID Number (NIK), e-identity card $(E-K T P)$ and family card $(K K)$. Therefore, they are not easily exploited. There are several kinds of misuse of data such as data sales, profiling data, marketing purposes, research, even including monitoring / espionage. What is more dangerous is the misuse of personal data for criminal acts such as creating fake accounts, fraud, money laundering, extortion and illegal transactions (Wijayanto, H., Muhammad, A. H., \& Hariyadi, D., 2020). In this case, the organizer's debt collector as an online lender is considered negligent and violates the law because it spreads personal data or customer contact details of the loan recipient without the consent of the customer who receives the loan, the debt collector collects improper billing by threatening the victim, and then collecting the debt as well.

This is done by calling the emergency contact filled in case of emergency things, the function of the emergency contact will definitely be contacted in the event of default from the borrowing consumer. In this case, the third party as the debt collector also accesses without permission to contact the customer phone list of the debtor and contacts and disseminates personal information to parties who have nothing to do with the borrower's debt. This is, of course, detrimental to the consumer's good name and violates the privacy of the party. Another result of spreading telephone contacts without clear consent, as for the consequences of this incident, is that around $21.48 \%$ of reports received were set to fire because of actions by debt collectors, the method of collecting debt by Rupiah Plus has gone through the private realm because it implements a digital persecution pattern. The Community Investigation team of fintech monitors get data that $89 \%$ (eightynine percent) of online loan fund recipients are victims of data disseminated by individual debt collectors (Novinna, V: 2021).

In practice, at fintech organizers there are illegal fintech organizers and commit violations. The majority of these illegal fintechs often create debt collection activities by intimidating and violating the privacy rights of customers as consumers. When the recipient of the loan is unable to pay off his overdue debt, usually the lender collects threats, intimidation, even takes physical action, not only to the loan recipient who is threatened and intimidated, but also to the friends and families of the loan recipient who are considered responsible for repaying the debt (Tendiyanto, T., 2021). This action violates not only the privacy of the debtor, but also the third parties contacted by fintech companies for billing purposes. In the legal context in Indonesia, breaches of data privacy can only be punished by imposing administrative sanctions on fintech. The problem that will arise next is that if the company is an illegal fintech? This will make it difficult for the mechanism to report data privacy breaches.

Violation in the practice of collecting debt at fintech is sexual harassment in which the borrower's photo is vulgarly edited and she is asked to engage in prostitution in order to pay off the debt. This act is punishable by Article 27 of Law 
Number 11 Year 2008 concerning Electronic Information and Transactions which stipulates that (1) Everyone who knowingly and without rights distributes and/or transmits and/or accesses Electronic Information and/or Electronic Documents that have content that violates decency is punishable by law.

The head of the Investment Alert Task Force, Tongam L. Tobing, explained that fintech is illegal to intimidate when it comes to debt collection, which leads to sexual harassment by asking for the nude photos of fintech users. This way the debt collector offers two options, first, asking the customers to pay at least one instalment and second, asking the customers to send nude photos as collateral for their debts. Then there is also someone who bills roughly by asking for video call sex and he will pay off the debt of the customer that has not been paid (https://finance.detik.com/fintech/d-

4873881/ngerinya-terjerat-pinjol-ilegal-dimintafoto-bugil).

On average, illegal online debt collectors commit defamation, coercion and threats in collecting debt. This kind of misdeed is governed in the criminal law. However, there are still shortcomings in that the police must accept the complaint offense first before being able to take action, even though this case is not actually a complaint offense. Legal problems also occur since most online loan providers are based abroad. Meanwhile, the number of online loan providers in Indonesia are only around 20 percent of the total (Nurwahridya, M. M., 2021). Insult or defamation caused by the misuse of personal data of peer to peer lending loan recipients can be said to be very fatal because almost all contact lists on mobile are contacted by debt collectors notifying that the loan recipients have debt and must immediately pay off the debt. In this case, it can be said that there has been misuse of personal data causing risks to loan recipients (Shofiyah, EN, \& Susilowati, IF, 2019).

Defamation is a special form of illegal action. There are some terms used to refer to this kind of illegal action. Some say it is defamation. However, others say it is an insult. Actually, the measure of an act that can be categorized as defamation of another person is still unclear because there are many factors that need to be re-examined. In the case of defamation or insult, what is to be protected is the obligation of each person to respect others from the point of view of his honor and good name in the eyes of others even though the person has committed a serious crime (Lumenta, A., 2020). The criminal threat of insulting and/or defamation in cyberspace is provided for in Article 27 paragraph (3) of Law Number 11 of 2008 concerning Electronic Information and Transactions, which stipulates that everyone who deliberately and without rights distributes and/or transmits and/or accesses Electronic Information and/or Electronic Documents that have the contents of insult and/or defamation is punishable by law.

Insult and/or defamation is an act that attacks honor. Honor is a person's respect in the eyes of society, in which everyone has the right to be treated as an honorable member of society. To attack honor means to do something according to the general judgment of attacking one's honor. Respect and actions that are categorized as attacking someone's honor are determined according to the community environment in which the act is committed, while good name is a good judgment according to the general assumption of a person's behavior or personality from a moral point of view. A person's good name is always seen from another angle, namely good morals or personality; therefore, the measure is determined based on general assessment, in a particular society where the action is committed and the context of the action (Mudzakir, 2004).

Ethical violations in debt collection practices at fintech are threatening collections. Regarding this matter, Law Number 11 of 2008 concerning Electronic Information and Transactions states that everyone who knowingly and without rights distributes and/or transmits and/or accesses Electronic Information and/or Electronic Documents that contain extortion and/or threat is punishable by law (Article 27 paragraph (4) of Law Number 11 Year 2008 concerning Information and Electronic Transactions). The provisions regarding threats are provided for in Article 369 of the Criminal Code which stipulates that: (1) Any person who with the intention of benefiting himself or another person unlawfully is under threat of defamation either verbally or in writing, or by threatening to reveal a secret, forces someone to give something that belongs wholly or partly to that person or someone else or in order to create a debt or write off a debt, shall be sentenced to up to four years in jail.

Article 29 of Law Number 11 Year 2008 concerning Electronic Information and Transactions further states that every person who intentionally and without right sends Electronic Information and/or Electronic Documents that contain threats of violence or intimidation aimed at personally is punishable by law. The provisions of this Section 29 are similar to the cyberstalking arrangements in the United States, Canada, United Kingdom and other countries. The provisions in these countries regulate acts of harassment, threats, 
or other actions taken to cause fear, either with words or certain actions. These acts are carried out using or through information and communication technology, for example by unsolicited hate mail, observations or threatening emails, mail bombs and others (Sigid Suseno, 2014). Debt Collectors at fintech companies follow borrowers wherever they go as long as they are connected in cyberspace. This stalking is also done by contacting people who are in the contact data on the borrower's cell phone. Thus, the borrower will feel intimidated and follow the debt collector's wishes, including making payments that are out of the ordinary.

\section{Conclusions}

Cyber-ethic transforms traditional ethics into ethics in cyberspace. Cyber-ethic is applied in various business fields in cyberspace, including fintech. The application of cyber-ethic in the fintech business is carried out by protecting the personal data of borrowers. Protection of personal data is a protection of human rights. The presence of fintech, which is not registered with the Financial Services Authority, provides ample space for fintech companies to ask customers to pay loans with an amount that is out of the ordinary.

In practice, there are several violations in debt collection at fintech such as personal data breaches that violate not only the borrower's personal data but also the privacy of third parties registered in the borrower's customer mobile phone contact. Violations in debt collection are also a legal problem, namely sexual harassment, humiliation, threats and stalking. These actions are intended to pressure the borrowers to be willing to pay beyond the amount that should be paid. On the other hand, borrowing customers do not have broad access to protect themselves. Actions taken by debt collectors occur massively and attack the honor of customers.

\section{Acknowledgements}

Thanks are given to the Doctor of Law Program at Udayana University, promoters and copromotor in the completion of the author's dissertation. Thank you also to the Supreme Court of the Republic of Indonesia.

\section{References}

Achmad D.A. (2020). Ngerinya Terjerat Pinjol Ilegal: Diminta Foto Bugil! Retrieved April 1, 2021, from

https://finance.detik.com/fintech/d4873881/ngerinya-terjerat-pinjol-ilegaldiminta-foto-bugil https://keuangan.kontan.co.id/news/afpi- penagihan-tidak-beretika-paling-diadukankonsumen-fintech-p2p

Adetimirin, A. (2017). Awareness and knowledge of cyber ethics by library and information science doctoral students in two Nigerian universities. International Journal of Technology Policy and Law, 3(1), 43-55.

Al-Mudimigh, A., \& Anshari, M. (2020). Financial technology and innovative financial inclusion. Financial technology and disruptive innovation in ASEAN, IGI Global. 119, 119129.

BF, A. R. H., Wisudawan, I. G. A., \& Setiawan, Y. (2020). Pengaturan Bisnis Pinjaman Secara Online atau Fintech Menurut Hukum Positif di Indonesia. Ganec Swara, 14(1), 464-475.

Dewi, S. (2009). Cyber law: Perlindungan privasi atas informasi pribadi dalam e-commerce menurut hukum internasional. Bandung: Widya Padjajaran.

Fachrurrazy, M., \& Siliwadi, D. N. (2020). Regulasi dan Pengawasan Fintech di Indonesia: Persfektif Hukum Ekonomi Syariah. Al-Syakhshiyyah Jurnal Hukum Keluarga Islam dan Kemanusiaan, 2(2), 154171.

Fahrimal, Y. (2018). Netiquette: Etika Jejaring Sosial Generasi Milenial dalam Media Sosial. Jurnal Penelitian Pers dan Komunikasi Pembangunan, 22(1), 69-78.

Fardiyan, A. R. (2016). Etika Siber dan Signifikansi Moral Dunia Maya. Prosiding Seminar Nasional Komunikasi: Akselerasi Pembangunan Masyarakat Lokal Melalui Komunikasi dan Teknologi Informasi, 331337.

Lumenta, A. (2020). Tinjauan Yuridis terhadap Tindak Pidana Pencemaran Nama Baik Menurut KUHP dan Undang-Undang Nomor 19 Tahun 2016 tentang ITE. Lex Crimen, 9(1).24.

Mudzakir. (2004). Delik Penghinaan dalam Pemberitaan Pers Mengenai Pejabat Publik. Jakarta: Dictum.

Nasrullah, R. (2017). Media Sosial Perspektif Komunikasi, Budaya, dan Sosioteknologi. Bandung: Simbiosa Rekatama Media.

Nasrullah, R. (2014). Teori dan riset media siber (cybermedia). Jakarta:

Kencana Prenadamedia Group.

Novinna, V. Perlindungan Konsumen dari Penyebarluasan Data Pribadi oleh Pihak Ketiga: Kasus Fintech "Peer to Peer Lending". Jurnal Magister Hukum Udayana, 9(1), 92-110. 
Nurdiani, I. P. (2020). Pencurian Identitas Digital Sebagai Bentuk Cyber Related Crime. Jurnal Kriminologi Indonesia, 16(2).

Nurwahridya, M. M. Peranan Polri dalam Penanggulangan Tindak Pidana Siber oleh Desk Collector Pinjaman Online. Jurnal Hukum Pidana dan penanggulangan Kejahatan, 9(1), 43-49.

Otoritas Jasa Keuangan. (2021). Penyelenggara Fintech Lending Terdaftar dan Berizin di OJK per 10 Januari 2021, Retrieved April 1, 2021, fromhttps://www.ojk.go.id/id/kan

Priskarini, I. A., \& Tejomurti, K. (2019). The Role of The Financial Services Authority in The Legal Protection of Privacy Rights in Connection with Personal Data of Fintech Lending Debtor in Indonesia. Padjadjaran Journal of Law, 6(3), 556-575.

Ramadhon, F. N. (2019). Pasar Masyarakat Digital dan Degradasi Netiquette. Jurnal Komunikasi, 13(1), 73-82.

Suseno, Sigid. (2012). Yurisdiksi Tindak Pidana Siber, Bandung: Refika Aditama.

Shayganmehr, M., Kumar, A., Garza-Reyes, J. A., \& Moktadir, M. A. (2021). Industry 4.0 enablers for a cleaner production and circular economy within the context of business ethics: a study in a developing country. Journal of Cleaner Production, 281, 125280.

Shkodina, I., Timoshenkov, I., \& Nashchekina, O. (2018). The impact of financial technology on the transformation of the financial system. Фінансово-кредитна діяльність: проблеми теорії та практики, (1), 417-424.

Shofiyah, E. N., \& Susilowati, I. F. (2019). Penyalahgunaan Data Pribadi Penerima Pinjaman dalam Peer to Peer Lending. Novum Journal, 1(2), 1-6.

Sinaga, H. D. E., Irawati, N., \& Kurniawan, E. (2019). Financial Technology: Pinjaman Online, Ya atau Tidak. Jurnal Tunas, 1(1), 14-19.

Suharini, S., \& Hastasari, R. (2020). Peran Otoritas Jasa Keuangan terhadap Fintech Ilegal di Indonesia sebagai Upaya Perlindungan pada Konsumen. Jurnal Akrab Juara, 5(3), 25-38.

Tendiyanto, T. (2021). Pelanggaran Penyelenggara Peer to Peer (P2P) Lending Financial Technology Ilegal Terhadap Debitur. Logika: Jurnal Penelitian Universitas Kuningan, 12(01), 85-93.

Terminanto, A. A. (2020). Analisa Penyelesaiaan Transaksi Penagihan Fintek Tanpa Adanya Jaminan. Zhafir| Journal of Islamic Economics, Finance and Banking, 2(1), 1-14.
Tira Santia. (2020). Penyaluran Pinjaman Fintech P2P Lending di 2020 Capai Rp 74,41 Triliun. Retrieved April 1, 2021, from https://www.liputan6.com/bisnis/read/44855 32/penyaluran-pinjaman-fintech-p2plending-di-2020-capai-rp-7441-triliun.

Wahyuni, R. A. E., \& Turisno, B. E. (2019). Praktik Finansial Teknologi Ilegal dalam Bentuk Pinjaman Online Ditinjau dari Etika Bisnis. Jurnal Pembangunan Hukum Indonesia, 1(3), 379-391.

Wijayanto, H., Muhammad, A. H., \& Hariyadi, D. (2020). Analisis Penyalahgunaan Data Pribadi dalam Aplikasi Fintech Ilegal dengan Metode Hibrid. Jurnal Ilmiah SINUS, 18(1), 1-10.

Yuliana, R. R. R. D. (2019). Sinergi Lembaga Teknologi Finansial dan Koperasi dalam Pemanfaatan Teknologi Finansial oleh Usaha Mikro, Kecil, dan Menengah di NTB. Jurnal Ekonomi dan Pembangunan, 27(1), 53-66.

Yudho Winarto (ed). AFPI: Penagihan tidak beretika paling diadukan konsumen fintech P2P. Retrieved April 1, 2021, from https://keuangan.kontan.co.id/news/afpipenagihan-tidak-beretika-paling-diadukankonsumen-fintech-p2p. 